\title{
PENINGKATAN KINERJA GURU KELAS IV DALAM MENETAPKAN KRITERIA KETUNTASAN MINIMAL MELALUI KELOMPOK KERJA GURU DI GUGUS II KECAMATAN SUMOBITO
}

\author{
Rahayu Setiyawati \\ Dinas Pendidikan Kabupaten Jombang \\ Email: rahayusetya14@gmail.com
}

\begin{abstract}
In setting the KKM (inimal submission criteria), the teacher has not been based on analysis and has not noticed the principles and determination measures. Therefore, there must be activities that can provide information to teachers who are used as guidelines in the determination of the KKM. The purpose of this research is to increase the ability of class IV teachers to set the KKM through group of teacher (KKG) in cluster II in Sumobito subdistrict. The subject of this research is the teacher at SDN class IV cluster II Sumobito subdistrict. The research object is the ability of teachers to establish Minimal submission criteria. Based on the analysis it gained that there was increased readiness and performance of the teacher in setting the minimum survival criteria from cycle I to cycle II. The achievement of performance indicators is in action II. In addition, there has been an increase in the teacher's ability to set Minimal submission criteria through a KKG-shaped coaching from cycle I to cycle II and achieve a set minimum target of $85 \%$, meaning that $85 \%$ of teachers are effective in establishing Minimal submission criteria. Thus it can be advised to other supervisors or researchers that the KKG activities can be used as an alternative in improving the performance of teachers in setting the minimum submission criteria.
\end{abstract}

Keyword: performance development of teacher, group of teacher, minimum submission criteria

Abstrak: Dalam menetapkan KKM (Kriteria Ketuntasan Minimal), guru belum berdasarkan analisis dan belum memperhatikan prinsip serta langkah-langkah penetapan. Oleh karena itu perlu ada kegiatan yang dapat memberikan informasi kepada guru yang dijadikan pedoman dalam penetapan KKM. Tujuan penelitian ini adalah meningkatkan kemampuan guru kelas IV dalam menetapkan Kriteria Ketuntasan Minimal (KKM) melalui KKG di Gugus II Kecamatan Sumobito. Subjek penelitian ini adalah guru SDN Kelas IV Gugus II Kecamatan Sumobito. Objek penelitian adalah kemampuan guru dalam menetapkan Kriteria Ketuntasan Minimal. Berdasarkan analisis diperoleh bahwa terjadi peningkatan kesiapan dan kinerja guru dalam menetapkan kriteria ketuntasan minimal dari siklus I ke siklus II. Ketercapaian indikator kinerja terdapat pada tindakan II. Selain itu, terjadi peningkatan kemampuan guru dalam menetapkan Kriteria Ketuntasan Minimal melalui pembinaan berbentuk KKG dari siklus I ke siklus II dan mencapai target minimal yang telah ditetapkan yakni $85 \%$, artinya $85 \%$ guru telah efektif dalam menetapkan Kriteria Ketuntasan Minimal. Dengan demikian dapat disarankan kepada pengawas atau peneliti yang lain bahwa kegiatan KKG dapat dipakai sebagai salah satu alternatif dalam meningkatkan Kinerja guru dalam menetapkan kriteria ketuntasan minimal.

Kata kunci : peningkatan kinerja guru, kelompok kerja guru, kriteria ketuntasan minimal

Kurikulum berbasis kompetensi yang menggunakan acuan kriteria dalam penilaian, mengharuskan pendidik dan satuan pendidikan menetapkan KKM dengan analisis dan memperhatikan mekanisme, yaitu prinsip dan langkahlangkah penetapan. Penetapan Kriteria Ketuntasan Minimal (KKM) merupakan tahapan awal pelaksanaan penilaian hasil belajar sebagai bagian dari langkah pengembangan Kurikulum Tingkat Satuan Pendidikan (Mursalin, 2016).

Kenyataan di lapangan guru dalam menetapkan KKM tidak berdasarkan analisis dan tidak memperhatikan prinsip serta langkah-langkah penetapan, oleh karena itu perlu ada kegiatan pada awal tahun pelajaran yang dapat memberikan informasi kepada guru yang dijadikan pedoman dalam penetapan KKM. 


\section{METODE PENELITIAN}

Penelitian ini merupakan penelitian tindakan (action research) yang bertujuan untuk meningkatkan kemampuan guru kelas IV dalam menetapkan Kriteria Ketuntasan Minimal melalui KKG di gugus II Kecamatan Sumobito. Tindakan yang dilakukan adalah Peningkatan Kemampuan Guru dalam Menetapkan Kriteria Ketuntasan Minimal. Jenis penelitian tindakan yang dipilih adalah jenis emansipatori. Emansipatori merupakan jenis penelitian penididkan dimana peserta dan fasilitator berkolaborasi dalam mengembangkan kompetensi yang dimiliki oleh guru (Prasetyo, 2011). Jenis emansipatori ini dianggap paling tepat karena penelitian ini dilakukan untuk mengatasi permasalahan pada wilayah kerja peneliti sendiri berdasarkan pengalaman sehari-hari. Dengan kata lain, berdasarkan hasil observasi, refleksi diri, guru bersedia melakukan perubahan sehingga kinerjanya sebagai pendidik akan mengalami perubahan secara meningkat (Al Rasyid, 2015). Rancangan penelitian yang digunakan adalah rancangan model Kemmis yang terdiri atas empat langkah, yakni : perencanaan, pelaksanaan, observasi dan refleksi (Kemmis et al., 2013). Penelitian ini akan dilaksanakan dalam beberapa siklus, dan langkah-langkah setiap siklus terdiri dari perencanaan, pelaksanaan, observasi dan refleksi. Kalau pada siklus satu tidak berhasil, maka siklus kedua bisa dilaksanakan.

\section{HASIL PENELITIAN}

\section{Deskripsi Kondisi Awal}

Gambaran hasil yang didapat berdasarkan rekaman fakta/observasi di lapangan, para guru pada awalnya pemahaman terhadap Kriteria Ketuntasan Minimal masih sangat kurang, hal ini dikarenakan persepsi guru menganggap bahwa Kriteria Ketuntasan Minimal tidak terlalu penting (Kartowigaran, 2011), disamping itu acuan, pelatihan, atau sosialisasi KKM juga kurang.

Dari 18 orang guru yang dapat dihubungi dan diobservasi diperoleh hasil sebagai berikut : a. Menetapkan KKM dengan analisis dan memenuhi mekanisme penetapan terdapat 0 orang $(0 \%)$.

b. Menetapkan KKM dengan analisis dan memenuhi mekanisme, tetapi tidak disahkan oleh Kepala Sekolah, dan pernah mengikuti pelatihan KKM sebanyak 4 orang (22\%)

c. Pernah mengikuti pelatihan dan menetapkan KKM tanpa analisis sebanyak 2 orang (11\%)

d. Menetapkan KKM tanpa analisis, karena belum pernah mengikuti pelatihan sebanyak 12 orang (66\%)

Dengan kondisi awal seperti ini perlu adanya tindakan nyata yang diharapkan mampu meningkatkan kemampuan guru dalam menetapkan Kriteria Ketuntasan Minimal.

\section{Deskripsi siklus I ( Pertama )}

a. Perencanaan terdiri atas :

1) Berkoordinasi dengan Kepala Sekolah untuk menyampaikan penelitian dan minta masukan tentang masalah yang ada sekaligus membicarakan masalah teknis, waktu pelaksanaan penelitian, dan hal-hal yang terkait dengan penelitian dan/atau KKG yang dilaksanakan (Resmini, 2010).

2) Bersama Kepala Sekolah memberikan materi Kriteria Ketuntasan Minimal.

3) Menelaah konsep Kriteria Ketuntasan Minimal

4) Mendiskusikan konsep Kriteria Ketuntasan Minimal dan presentasi kelompok.

5) Presentasi Kelas.

6) Menghasilkan KKM

Disamping perencanaan umum, ada juga perencanaan teknis pelaksanaan kegiatan seperti :

1) Mengumpulkan guru melalui undangan Kepala Sekolah

2) Menyusun Jadwal KKG: hari, tanggal, jam, dan tempat

3) Menyiapkan materi KKG.

4) Menyuruh guru membawa bahan-bahan seperti kurikulum, silabus, RPP, dan sebagainya (Purnanda, 2013).

5) Menyiapkan konsumsi untuk KKG. 
6) Menyuruh guru membawa Laptop (minimal ada 4 laptop dan 1 LCD).

b. Pelaksanaan Tindakan

Pada tahap ini dilakukan berbagai langkah yakni :

1) Absensi peserta

2) Pengarahan umum pada seluruh peserta

3) Peserta dikelompokkan

4) Mengkaji Kompetensi Inti (KI), Kompetensi Dasar (KD) dan Indikator yang ada pada silabus

5) Guru membuat analisis per indikator

6) Presentasi visual Kriteria Ketuntasan Minimal

c. Hasil observasi

Pada tahap ini dilakukan pengamatan terhadap pelaksanaan tindakan, yaitu menitik beratkan pada kompetensi guru dalam menetapkan Kriteria Ketuntasan Minimal sebagai akibat diterapkan KKG (Alwi, 2009). Tujuan dilaksanakan pengamatan adalah untuk mengetahui kegiatan mana patut dipertahankan, diperbaiki, atau dihilangkan sehingga kegiatan pembinaan melalui KKG benarbenar berjalan sesuai dengan tujuan yang ada dan mampu meningkatkan kemampuan peserta dalam menetapkan Kriteria Ketuntasan Minimal.

Kegiatan peserta juga diobservasi, mengenai kesiapan mental dan fisik guru, kesiapan bahan-bahan yang dibawa guru pada waktu KKG, kehadiran guru, kesiapan laptop, kualitas KKM, dan respon guru.

Dari hasil pengamatan terhadap aktivitas peserta yang berjumlah 18 orang dengan menggunakan lembar observasi yang telah disiapkan, diperoleh data sebagai berikut :

Tabel 1. Rangkuman hasil observasi tentang kesiapan guru dalam mengikuti KKG pada siklus I.

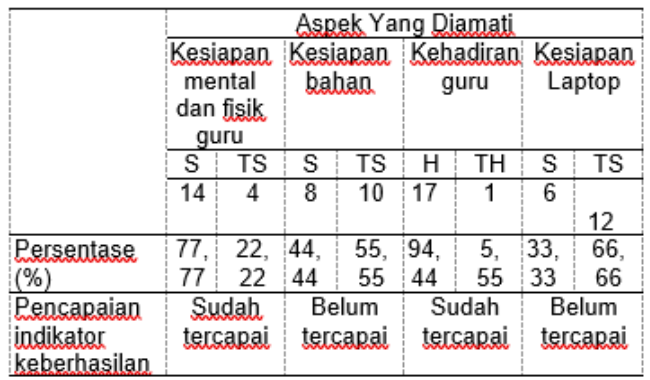

Dari tabel 4.1. diatas, tampak bahwa pada aspek kesiapan mental dan fisik; 14 orang atau $77,77 \%$ peserta siap dan 4 orang atau 22,22\% tergolong belum siap. Pada aspek kesiapan bahan tampak 8 orang atau $44,44 \%$ peserta siap dan 10 orang atau $55,55 \%$ belum siap. Pada aspek kehadiran guru tampak 17 atau 94,44\% hadir dan 1 orang atau 5,55\% tidak hadir. Pada aspek kesiapan laptop tampak 6 orang atau 33,33 $\%$ siap dan 12 orang atau 66,66 \% belum siap. Berdasarkan deskripsi ini tampaknya kesiapan guru dalam mengikuti KKG belum memenuhi kriteria keberhasilan untuk semua aspek.

Dari hasil evaluasi terhadap penetapan KKM yang dibuat oleh 18 orang yang mengikuti KKG pada siklus I seperti tampak pada tabel 4.2. berikut:

Tabel 2. Rangkuman Hasil Penilaian Guru terhadap langkah-langkah Penetapan KKM pada siklus I.

\begin{tabular}{|c|c|c|c|c|}
\hline $\begin{array}{l}\mathrm{N} \\
\mathrm{O}\end{array}$ & Aspek & $\begin{array}{c}\text { Jumlah } \\
\text { Nilai }\end{array}$ & $\begin{array}{c}\text { Rata- } \\
\text { rata } \\
\text { Nilai }\end{array}$ & $\begin{array}{c}\text { Per } \\
\text { sen } \\
\text { tase }\end{array}$ \\
\hline 1 & $\begin{array}{l}\text { Penetapan } \\
\text { KKM mata } \\
\text { pelajaran } \\
\text { memperhatikan } \\
\text { tiga aspek; } \\
\text { kompleksitas, } \\
\text { daya dukung, } \\
\text { dan intake }\end{array}$ & 3.300 & $\begin{array}{l}84, \\
62\end{array}$ & $\begin{array}{l}84 \\
62\end{array}$ \\
\hline 2 & $\begin{array}{l}\text { KKM dibuat per } \\
\text { indikator, } \\
\text { kemudian KD, } \\
\mathrm{KI} \text {, dan terakhir } \\
\text { mata pelajaran }\end{array}$ & 2.350 & $\begin{array}{l}60 \\
26\end{array}$ & $\begin{array}{l}60 \\
26\end{array}$ \\
\hline 3 & $\begin{array}{l}\text { Hasil } \\
\text { penetapan KKM } \\
\text { oleh guru mata } \\
\text { pelajaran } \\
\text { disahkan oleh } \\
\text { kepala sekolah }\end{array}$ & 3.300 & $\begin{array}{l}84, \\
62\end{array}$ & $\begin{array}{l}84 \\
62\end{array}$ \\
\hline 4 & $\begin{array}{l}\text { KKM yang } \\
\text { ditetapkan } \\
\text { disosialisasikan } \\
\text { kepada pihak- } \\
\text { pihak yang } \\
\text { berkepentingan } \\
\text { yaitu peserta }\end{array}$ & 3.900 & 100 & 100 \\
\hline
\end{tabular}




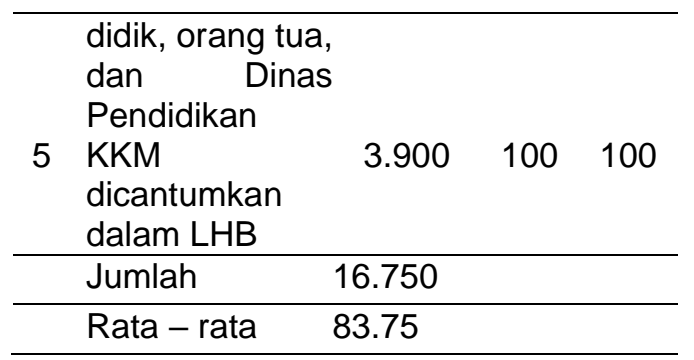

Keterangan :

Amat Baik $=85<A \leq 100$

Baik $=70<B \leq 85$

Cukup $=56<\mathrm{C} \leq 70$

Kurang $=\leq 56$

Dari tabel 4.2. diatas pada aspek Penetapan KKM mata pelajaran memperhatikan kompleksitas, daya dukung dan intake dalam katagori baik, pada aspek $\mathrm{KKM}$ dibuat per indikator, kemudian $\mathrm{KD}, \mathrm{KI}$, dan terakhir mata pelajaran dalam katagori cukup, aspek pengesahan oleh Kepala Sekolah berada pada kagori baik, kemudian untuk aspek nomor 4 dan 5 bagaimanapun caranya guru mendapatkan KKM pasti disosialisasikan pada siswa, orang tua, dan ditulis dalam LHB.

Berdasarkan deskripsi pada tabel 4.1. dan 4.2. tampaknya kemampuan guru dalam menetapkan Kriteria Ketuntasan Minimal belum memenuhi indikator kinerja yang telah ditetapkan (Karweti, 2010) pada semua aspek (kecuali aspek 4 dan 5).

\section{Deskripsi Hasil Siklus II (kedua)}

Pada siklus II, langkah-langkah yang diambil sesuai dengan refleksi hasil siklus I, dengan memfokuskan pada penjelasan aspek-aspek yang belum dipahami guru dalam menetapkan Kriteria Ketuntasan Minimal, lebih menitik beratkan pada aspek pembimbingan secara individu. Dari 18 orang guru semua dilibatkan dalam siklus II untuk memperdalam pengetahuan tentang penetapan Kriteria Ketuntasan Minimal. Setelah siklus II dijelaskan yang mengacu pada refleksi dan pemecahan masalah pada siklus I diperoleh data seperti tampak pada tabel 4.3.

Tabel 3. Rangkuman Hasil Observasi Tentang Kesiapan Guru dalam mengikuti KKG pada siklus II.

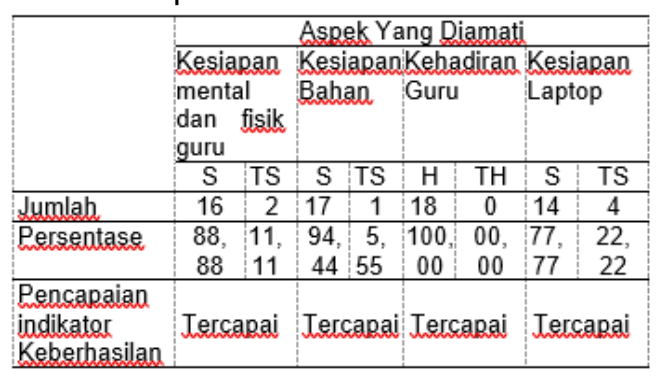

Dari tabel 4.3. diatas, tampak bahwa : pada aspek kesiapan mental dan fisik 16 orang atau $88,88 \%$ siap dan 2 orang atau $11,11 \%$ tidak siap. Pada aspek kesiapan bahan tampak bahwa 17 orang atau 94,44\% siap dan 1 orang atau 5,55\% tidak siap. Pada kehadiran 18 orang hadir atau $100 \%$ dan 0 orang atau $0 \%$ tidak hadir. Pada aspek kesiapan laptop tampak bahwa 14 orang atau $77,77 \%$ siap dan 4 orang atau $22,22 \%$ tidak siap.

Berdasarkan deskripsi ini tampaknya kesiapan guru dalam mengikuti KKG sudah memenuhi $100 \%$ untuk semua aspek, mungkin karena kebanyakan guru membutuhkan materi yang selalu dibutuhkan ketika mengajar.

Dari hasil evaluasi terhadap penetapan Kriteria Ketuntasan Minimal oleh guru yang mengikuti KKG pada siklus II diperoleh hasil seperti pada tabel 4.4. berikut.

Tabel 4. Rangkuman Hasil Penilaian Guru Dalam Penetapan Kriteria Ketuntasan Minimal pada siklus II.

\begin{tabular}{lll}
\hline $\mathrm{N}$ A s p e k $\begin{array}{c}\text { Jumlah } \\
\text { Nilai }\end{array}$ & $\begin{array}{c}\text { Rata- } \\
\text { rata } \\
\text { Nilai }\end{array}$ & $\begin{array}{c}\text { Persen } \\
\text { tase }\end{array}$ \\
\hline 1 Penetapan KKM 4.000 & 100 & 100 \\
mata pelajaran & & \\
memperhatikan & & \\
tiga aspek: & & \\
kompleksitas, \\
daya dukung, \\
dan intake. \\
2 KKM dibuat per 2.650 \\
indikator, \\
kemudian KD, KI
\end{tabular}


Rahayu Setiawati, Peningkatan Kinerja Guru Kelas IV Dalam Menetapkan Kriteria Ketuntasan Minimal Melalui Kelompok Kerja Guru di Gugus II Kecamatan Sumobito 91

\begin{tabular}{|c|c|c|c|c|}
\hline & dan terakhir mata & & & \\
\hline 3 & pelajaran & 4.000 & 100 & 100 \\
\hline & Hasil penetepan & & & \\
\hline & KKM oleh guru & & & \\
\hline & mata pelajaran & & & \\
\hline & disahkan oleh & & & \\
\hline 4 & Kepala Sekolah & 4.000 & 100 & 100 \\
\hline & KKM & & & \\
\hline & ditetapkan & & & \\
\hline & disosialisasikan & & & \\
\hline & kepada pihak- & & & \\
\hline & pihak yang & & & \\
\hline & berkepentingan, & & & \\
\hline & yaitu peserta & & & \\
\hline & didik, orang tua, & & & \\
\hline & Dinas & & & \\
\hline & Pendidikan & & & \\
\hline 5 & $\mathrm{KKM}$ & 4.000 & 100 & 100 \\
\hline & $\begin{array}{l}\text { dicantumkan } \\
\text { dalam LHB }\end{array}$ & & & \\
\hline & Jumlah Nilai & 18,650 & & \\
\hline & Rata-rata & 93,25 & & \\
\hline
\end{tabular}

Dari tabel 4.4. diatas, bila dilihat dari rata-rata secara umum dalam penetapan Kriteria Ketuntasan Minimal pada siklus II berada pada amat baik (rata-rata 93,25), namun ada satu aspek yang belum mencapai $100 \%$, bahkan berada pada Kriteria cukup yaitu pada aspek 2 (KKM dibuat per indikator, kemudian $\mathrm{KD}, \mathrm{KI}$, terakhir mata pelajaran) (Mardapi et al., 2015).

Untuk hal ini dapat dijelaskan bahwa pada guru kelas di KKG gugus II Kecamatan Sumobito ini ada 3 orang guru yang sudah berusia lebih dari 50 tahun yang kesulitan dalam mengembangkan silabus, RPP, dan penetapan indikator pada $\mathrm{KD}, \mathrm{KI}$, dan mata pelajaran, sehingga akhirnya KKM dibuat tidak dibuat setiap indikator. Respon guru terhadap penetapan Kriteria Ketuntasan Minimal melalui KKG sangat baik dan antusias.

Penilaian ini penting dilakukan untuk memperoleh gambaran tentang respon guru terhadap kegiatan KKG yang telah di harapkan dalam menetapkan Kriteria Ketuntasan Minimal. Jika kita lihat dari nilai atau persentase guru yang dapat menetapkan KKM dengan memenuhi mekanisme dari kajian awal, siklus I, dan siklus II adalah 6\%, 83,75\%, dan kemudian $93,25 \%$ ini menunjukkan peningkatan yang sangat berarti. Jadi dapat dikatakan bahwa respon guru sangat positif Oleh karena itu, penerapannya perlu dilanjutkan dalam kegiatan-kegiatan yang lain.

\section{Kesimpulan}

Berdasarkan analisis dan pembahasan seperti yang telah dipaparkan sebelumnya, maka dapat disimpulkan bahwa :

1. Proses pelaksanaan penetapan Kriteria Ketuntasan Minimal melalui KKG untuk peningkatan kemampuan guru dimulai dari supervisi awal. Supervisi awal dilakukan untuk mengenali masalah yang ada dalam penetapan Kriteria Ketuntasan Minimal. Langkah selanjutnya adalah menganalisis hasil supervisi kemudian ditindaklanjuti dengan mengadakan KKG.

2. KKG dilakukan dengan menggunakan tahapan-tahapan yang lebih menekankan pengetahuan praktis sehingga mudah dicerna oleh guru. Selanjutnya adalah memberikan latihan menetapkan Kriteria Ketuntasan Minimal sesuai dengan langkah-langkah yang telah ditentukan. Untuk meyakinkan guru membuat Kriteria Ketuntasan Minimal dilakukan presentasi pada masing-masing kelompok guru mata pelajaran. Peneliti mengamati dan menilai Kriteria Ketuntasan Minimal yang telah ditetapkan guru. Dari penilaian tersebut kemudian dievaluasi bagian mana yang belum sesuai dengan Kriteria, kemudian dilanjutkan dengan perbaikan. Melalui tahapan tersebut guru dalam menetapkan Kriteria Ketuntasan Minimal meningkat.

3. Terjadi peningkatan kesiapan peserta dalam kegiatan KKG di gugus II Kecamatan Sumobito. Disamping itu juga, terjadi peningkatan kemampuan guru dalam menetapkan Kriteria Ketuntasan Minimal melalui pembinaan berbentuk KKG dari siklus I ke siklus II dan mencapai target minimal yang telah ditetapkan yakni $85 \%$, artinya $85 \%$ guru telah efektif dalam menetapkan Kriteria Ketuntasan Minimal. Dengan demikian dapat disimpulkan bahwa melalui KKG dapat 
meningkatkan kemampuan guru dalam menetapkan Kriteria Ketuntasan Minimal.

4. Guru-guru kelas di sekolah dasar di KKG gugus II Kecamatan Sumobito memberikan respon yang sangat positif terhadap kegiatan penetapan Kriteria Ketuntasan Minimal melalui KKG. Dengan demikian kegiatan KKG memberikan dampak positif terhadap kemampuan guru dalam menetapkan Kriteria Ketuntasan Minimal

\section{Daftar Rujukan}

Al Rasyid, H. (2015). Fungsi Kelompok Kerja Guru Bagi Pengembangan Keprofesionalan Guru Sekolah Dasar. Sekolah Dasar, 24(2), 143-150. http://download.portalgaruda.org/article.p hp?article $=461652 \& v a l=5095 \&$ title $=F U N$ GSI KELOMPOK KERJA GURU (KKG) BAGI PENGEMBANGAN KEPROFESIONALAN GURU SEKOLAH DASAR

Alwi, M. (2009). Peran Kelompok Kerja Guru (Kkg) Dalam Meningkatkan Profesional Guru Sains Sekolah Dasar Kecamatan Suralaga. 4(2), 101-117.

Kartowigaran, B. (2011). Kinerja Guru Profesional (Guru Pasca Sertifikasi). Cakrawala Pendidikan, 30(3), 463-473.

Karweti, E. (2010). Pengaruh Kemampuan Manajerial Kepala Sekolah Dan Faktor
Yang Mempengaruhi Motivasi Kerja Terhadap Kinerja Guru SLB Di Kabupaten Subang. Journal Penelitian Pendidikan, 11(2), 77-89.

Kemmis, S., McTaggart, R., \& Nixon, R. (2013). The Action Research Planner. Springer.

Mardapi, D., Hadi, S., \& Retnawati, H. (2015). Menentukan Kriteria Ketuntasan Minimal Berbasis Peserta Didik. Jurnal Penelitian Dan Evaluasi Pendidikan, 19(1), 38-45.

Mursalin, H. (2016). Peningkatan Kinerja Guru Dalam Menetapkan Kriteria Ketuntasan Minimal Belajar Melalui Workshop Pada SMA Granada PGRI Kota Banda Aceh. Jurnal Media Inovasi Edukasi, 02(05), 152-161.

Prasetyo, Z. K. (2011). Penelitian Tindakan Kelas (PTK) dan Sistematika Laporannya.

Purnanda, A. (2013). PELAKSANAAN FUNGSI KELOMPOK KERJA GURU ( KKG ) DI SEKOLAH DASAR NEGERI ( SDN ) KECAMATAN SUNGAI TARAB. Bahana Manajemen Pendidikan, 1(1), 18.

Resmini, W. (2010). Pembinaan

Kemampuan Profesional Guru Melalui Kelompok Kerja Guru ( Kkg ). GaneÇ Swara, 4(1), 59-62. 